\title{
Galicia in Texts by Modern Ukrainian Authors: New Structures of "World Literature" Between Literature and Public History
}

\author{
Lesya Ivasyuk
}

\begin{abstract}
Re-defining the notion of "world literature" has become a challenge especially after the fall of the USSR and the appearance of many literatures whose background and content, both historical and mental, are rather unknown to Western Europe. The purpose of this article is to show the contradictions and the shortages of the modern theoretical approach to the notion of "world literature", especially with regard to the socalled post-communist countries. This article examines Galicia, a historical region representing the problematics of an approach to new "world literatures".

This article presents a number of the most representative case studies, which are analysed from the hermeneutical perspective. It shows that the 'Western' theories trying to establish a new notion of "world literature" have a tendency to ignore the specifics and historical background of the so-called post-communist countries, observing the process of literature in one-way fashion 'from West to East'. The notion of "world literature", however, is more complex than that offered in modern theories. It requires an interdisciplinary multilingual and historical approach with a platform for the transfer of knowledge and know-how between 'West' and 'East'. The mere accent on the shift of these literatures from a national to an international paradigm seems to fail to reflect the complexity of the problematics to the extent to which it is necessary to establish a new notion of "world literature".
\end{abstract}

In my approach to discovering new structures of "world literature", public history has to be considered one of the most important key concepts.

Index Terms-Public history, Ukrainian literature, USSR, world literature.

\section{INTRODUCTION}

Attempts to find new theoretical approaches to "world literature" began in the 90s, not least because of the fall of the communist regime in a number of states. The newly-found freedom had an immense impact on the quality and subjects of the literatures of the respective states, first of all because the opening the borders meant geographical and mental re-orientation.

A number of researchers contributed to finding a new theoretical framework, such as David Damrosch with his focus on the role of translation in 2003 in his book What is World Literature?, or Ottmar Ette, who distances himself from the Eurocentrism in ÜberLebenswissen. Die Aufgabe der Philologie [The Knowledge of Surviving and Life. The

Manuscript received January 28, 2019; revised March 21, 2019.

L. Ivasyuk was with Vienna University, Vienna, 1010, Austria. (e-mail: lesya.ivasyuk@univie.ac.at). task of Philology]' (2004). Pascal Casanova (The World Republic of Letters, 1999), Franco Moretti (Kurven, Karten, Stammbäume. Abstrakte Modelle für die Literaturgeschichte [Curves, Cards and Family Trees. Abstract Models for the History of Literature], 2005), and Emily Apter (The Translation Zone, 2006) also dealt with this subject, discovering new facets of the problematics. They rightly assume that world literature should not be a strict canon of aesthetically high-quality literature, but a phenomenon of an international field of diverse literatures that are not primarily dependant on any national paradigm.

This perspective, to which I often refer in this article, was presented in detail by Mads Rosendahl Thomsen in "Mapping World Literature. International Canonization and Transnational Literatures" in 2008.

My approach to the subject of "world literature" is interdisciplinary and is connected to the macro-historical situation coining the respective literatures. That is why the theories of Reinhart Koselleck and Hans Robert Jauß, relativizing the gap between fictitiousness and facticity, help us to create a framework for answering a number of crucial questions, e.g. how can "world literature" be re-formulated or what kind of contradictions do we face on the way to establishing this notion, especially with regard to the so-called post-communist literatures?

In the states that declared their independence after the fall of the communist regime in the USSR there began an essentially new phase of literary development and a different approach to the literary and historical past and present. The intensity and the quality of this process differ from country to country, whereby the Soviet ideology still has a strong influence in a number of cases. Additionally, the economic, political and mental dependencies on the former imperial centre and its continued compulsion to assert political control over the 'lost' territories of fourteen republics still play a role.

A glance at e.g. modern Kazakh or Belarussian literature is enough to understand the reason why in the case of these so very different states, located so far apart, but dependent on the same imperial centre for decades, we can hardly speak of a fully-fledged literary and intellectual life meeting the challenges of modern times. One of the many consequences of the communist language policy is the fact that UNESCO included the Belarussian tongue in its list of potentially endangered languages.

The critical situation of the Belarussian language, is emphasized by Ulrike Butmaloiu in her article Die belarussische Sprache ist vom Aussterben bedroht. Die weißrussische Familie Pawlowska im polnischen Zaluki [The 
Belarussian language is endangered. The White Russian family Pawlowska in the Polish Zaluki] in the book Minderheiten in Osteuropa. Die unbekannten Nachbarn [Minorities in the Eastern Europe. The Unknown Neighbours].

The issue of the decline of the Kazakh language and its political, historical and societal dimensions is the focus of Abduzhalil Abdurasulov's article B Казахстане обсуждают переход на латинииу [In Kazakhstan the transition to the Latin script is being debated] (2007). Thus in Kazakhstan one can observe a dramatic situation in which the Kazakh language plays an insignificant role in everyday communication and is almost inexistent in literature.

Ukrainian literature is more successful in this regard, although the totality and the strategic direction of the Russification and Sovietisation processes as well as a permanent elimination of the intellectual elites that went hand in hand with the creation of the communist literary canon, which in the so-called Ukrainian Socialist Soviet Republic became a si ne qua non of the official propaganda, had severe consequences which can still be felt in Ukraine today. The act of declaring Ukrainian the official language in the Ukrainian Socialist Soviet Republic in 1978 cannot be put forward as a counter-argument, because in the communist regime even the constitutions were declarative in character. This applies above all to the so-called freedom of the nationalities of the USSR or the "free" development of their languages and cultures. The juristic side of the communist language policy and the policy towards nationalities was deliberately deployed as a counter-play to what was going on in reality. Interesting findings in this respect are the results of the conference organized by the Institute of European History in Mainz. It is important to mention in this context Alexander R. Schejngeit's book Kampf um Wort und Schrift. Russifizierung in Osteuropa, im Kaukasus und in Sibirien im 19. bis 21. Jahrhundert [The Battle for Word and Script. Russification in the Eastern Europe, in the Caucasus and Siberia in the $19^{\text {th }}$ till $21^{\text {st }}$ Century].

It must be underlined that in the USSR the notions of "world literature" and "canon" were ideological and their content was strongly linked with and controlled by the political and linguistic-ideological centre, namely Russia. Over the course of time, the literary and historiographic traditions of the countries under the communist regime were marginalized by Soviet Russian-oriented literary scholarship and historiography. Their languages were largely replaced by Russian as the language of the imperial centre, and a non-ideological literary process was impeded. One of the most significant surveys and an informative collection of archive papers on the "lingvocide" of the Ukrainian language in the USSR was published in 2005 by Larysa Masenko under the title Українська мова у XX сторіччі. Iсторія лінгвоциду [The Ukrainian Language in the 20th Century. A History of a Lingvocide].

Hence in the intellectual circles of that time the canonization of literature was considered to be the canonization of the communist ideology. This was the reason why the canonization of "Soviet literature" and world literature, i.e. those parts of it which were allowed by censorship, were understood rather as an instrument of control over the representatives of diverse nationalities and as an instrument for the creation of a homo sovieticus loyal to the Party.

It is no wonder, then, that in the post-occupation states, e.g. in Ukraine, the agenda is shaped by processes of de-canonization comprehensible from the post-colonial perspective and the discovery of identities and languages that help form them, languages which were banned, impeded or eliminated. In this context, the question of reconstruction and understanding world literature is more relevant than ever before.

From the modern perspective, formulating a new notion of world literature in the countries after the fall of the communist system seems to be extremely complicated and complex, first of all because of the break with the regime that controlled the literary process, because of the vacuum in the theoretical-methodological field, but also because of the deficient instruments of mental self-positioning in these societies in general. At the same time, in the collective self-perception this politically determined and emotionally charged transition phase offers an opportunity to create a Europe-wide basis for a new approach to the notion of "world literature".

\section{UKRAINIAN LITERATURE’S SELF-POSITIONING}

Ukraine belongs to the few states after the fall of Communism to embark on a democratic process (the Maidan of 2006 and "the Revolution of Dignity" 2013-21014); a civil society is being developed and not only can writers speak freely, but they have even become leading public intellectuals to whom society listens intently, e.g. Oksana Zabuzhko, Stepan Prociuk or Serhii Zhadan.

The intellectuals took part, even if not too actively, in a step-by-step de-Sovietization of society on every level, including the discovery of the banned names, biographies, and literary and historical texts as a process of the recovery of historical and cultural memory. The opening of KGB archives and archives of other repressive organs in the course of de-communization, adopted by the Parliament in 2015, is an essential contribution to the fact that individuals are focusing more and more on issues such as memory, their families' past and personal stories of their relatives, but also the history of towns, villages and the country in general. In this context, oral history has begun to feature in Ukraine, having been ignored for a long time. This relatively new genre is being used to preserve all that had been forgotten and banned. An example of the research in the field of oral history is the internet platform of the Centre of the Research on the Ukrainian Legacy, which is also accessible in English online: http://drc.usask.ca/projects/pcuh/transformation/eng/

The guidelines of the Institute of National Memory (Kyiv) aim to establish intensive cooperation to inform the multi-ethnic population of Ukraine in order to enable a processing of the past on the individual and collective levels. In this context, a slow but efficient rapprochement is taking place between academia and the public.

The first fundamental analysis and statistics of the communist crimes, urgently needed by both academia and the 
public, were provided by Stéphane Courtois and her co-authors in Le Livre noir du communisme. Crimes, terreur, répression. [The Black Book of Communism. Crimes, Terror, Repression]. This coming to terms with history and the crimes of communism, painful for all societies that experienced it, the identity crises caused by the politics of the regime, the state of literature and languages in the former republics, but also the need to process the tragic events of the twentieth century, whose internalization will endure, in some countries, for decades - all this is usually underestimated in the Western European discourses and sometimes even goes unseen. This is inter alia the result of generally too slow a rapprochement on the part of the Western countries with the communist past of the respective states. In the German-speaking world it received interdisciplinary accentuation several years ago in the book by Frank-Lothar Kroll and Barbara Zehnpfennig Ideologie und Verbrechen. Kommunismus und Nationalsozialismus im Vergleich. [Ideology and Crime. Communism and National Socialism in Comparison], published in Munich in 2014.

This attitude also exacerbates the creation of a qualitatively new concept of "world literature".

One of the leading Ukrainian literary scholars, Solomiia Pavlychko, argued in 1999 for the de-canonization of world literature as a process which would enable Ukrainian literature to find its place among other world literatures:

"Глобальний процес деканонізації i знищення культурного центру вигідний для української літератури, яка може мріяти про своє місце в полі національних літератур, як це сталося з літературами Єгипту, Ізраїлю, Естонії, Нігерії та ін. [...] Сьогодні українська література переживає процес зламу [...] центру, або старого канону, i вироблення нових критеріїв його побудови. [...] Колоніальність полягала в тому, що все в ньому відбувалося за певною матрицею, певним зразком, яким служила російська література" [Pavlychko, 634, 2009], [1].

In Pavlychko's approach one can observe the alienation from the canonization of the Soviet times as a pattern via which particular literatures were made dependent and marginalized and the languages of the respective literatures became objects of an unwavering policy of elimination.

Neither in Ukraine nor in other states occupied by the Communists, nor in Western Europe, is there a platform for efficient knowledge transfer seeking to establish such new criteria for defining the "canon" of world literature.

In recent decades, a number of highly productive authors have appeared in Ukraine. Independently of which part of the country they were born in, many of them write in Ukrainian (Oksana Zabuzhko, Vasyl Shkliar, Stepan Prociuk et al.) or Russian (Andrii Kurkov, Konstiantyn Skorkin, Oleh Ladzhevskyi et al.), and a few in Crimean Tatar (Han-Temir, Tair Halilov, Hulnara Useiinova et al.).

The development of literatures of other minorities, e.g. Armenians, is a long time coming, not least because many Armenian intellectuals do not have a command of Armenian as a result of Russification. In the framework of migrant literature, mention must be made of Mariana Haponenko from Odessa, who lives in Vienna and Mainz and writes in German.
The texts of the modern Ukrainian authors have various qualities and genres, possess diverse thematic accents, and, due to the deficient infrastructure of the European book and publishing market, have a different "brand awareness". Generally, it can be said that the largest and the most impressive segment of Ukrainian literature - even if its variety does not permit any definite categorization - is characterised as a literature of self-reflections on time and space and of an individual rediscovery of collective fates. It creates an immense space for a sort of activation of memory. This description also applies to frequent cases of hidden escape from certain topics. Twenty-six years of freedom is not long for the development of literature. The de-canonization of what was imposed in the Soviet paradigm is still ongoing.

This means that in its search for a new approach to world literature, Ukraine is still looking for a specific, manifold and interdisciplinary path that could be elaborated by both literary scholars and historians, but also by representatives of other disciplines. In this way, an efficient platform should be created which on the one hand is international and interdisciplinary, and on the other is open to the public and effective in the transfer of literatures.

\section{A THEORETICAL APPROACH FROM THE WEST AND ITS DEFICITS}

If we understand Mads Rosendahl Thomsen's approach to world literature as a search for "constellations across time and space" [Thomsen, 3, 2008] and perceive literatures as carriers of specific perspectives which due to a number of qualities have to become integral parts of a new notion of "world literature", it is reasonable to ask what kind and what amount of prior knowledge is needed to approach the literature of states that became victims of the communist regime. How is it possible to approach the work of the literary generation after the fall of Communism and to perform an analysis of its backgrounds, preconditions, processes and actors that is well developed on the European scale and rich in perspectives? Thomsen provides no orientation in this direction. In his book, he explains the general patterns and his examples are restricted to some few literatures. In favour of Thomsen's "universality", the literatures after the fall of Communism are falling by the wayside. Despite their specifics, they are no less interesting in the context of this "universality". He rightly points out the shortcomings of a comparative and post-colonial approach whose interpretative patterns are often inadequate. A well-thought-out and differentiated view of the literatures after the fall of the communist system as a geopolitical, cultural, polylingual phenomenon both in the European and the global context seems all the more necessary. Here mention must be made of a valuable article collection on the "hybridity" as a feature of Slavic literatures which 'upgrades' them to the "world literature" under the title Slavische Literaturen der Gegenwart als Weltiteratur - hybride Konstellationen [Contemporary Slavic Literatures as World Literature. Hybrid Constellations] published in 2015. However, the theoretical borderlines set by Thomsen are still 
not overcome in this book.

It should be stressed that despite an essential sensitization of the Western European discourses towards East European texts, there still exists a noticeable East-West dichotomy which will inevitably impede the search for new structures of world literature, since from the 'Western European' perspective the 'Eastern European' exists as a 'strange' space, despite all attempts to overcome this. This is the case not least because the analytical and textual pool has yet to be built up, let alone mediated to the public, and there are not enough translations from e.g. Ukrainian or Belarussian into German or English.

Thomsen underlines that there are few non-Western authors who are well known in the West; but it is obvious that 'degrees of renown' both in Western and in Eastern Europe is a highly relative notion which depends on a number of aspects beyond the literary ability of the respective author.

It seems to be a paradox that despite globalization and discourses on it, the only works translated into German or English are the texts of those few authors of the post-Soviet era which have been well established on their respective domestic markets for many years. An important anthology in this context is The White Chalk of Days and Words, published in English in 2017. However, literary greats, e.g. the Ukrainian-speaking author Stepan Prociuk, Emil Amit, who wrote in Crimean Tatar, or Oles Ulianenko, whose Stalinka (1994) and The Woman of his Dreams (2009) have meanwhile become undisputable masterpieces of Ukrainian literature, remain largely unknown to a Western European readership. At least Stalinka was published in English in Toronto in January 2018 while I was working on this article, and is available online along with the texts of other Ukrainian authors: http://sites.utoronto.ca/elul/Ukr_Lit/Vol05/

Anette Werberger offers a candid view of the specifics of the Eastern European literatures and tries to understand literary history as a history of intertwinement. She proposes Austrian Galicia as an example of "intertwined history" and as a sort of model of Europe in her Überlegungen zu einer Literaturgeschichte als Verflechtungsgeschichte.[Reflections on Literary History as a History of Interconnections] (2012).

Indeed, in its cultural variety so-called Austrian Galicia is an interesting and, in terms of academic discourses, fruitful period, despite its brevity in the context of European history. But the question whether the existence of this administrative entity in the Habsburg Empire has been basically a story of success or failure, including on the level of its multicultural manifestation, remains largely open.

From my perspective, the matrix of the history of intertwinement is wide enough and happens to cover the mutual connections in the framework of Austrian Galicia as a culturally diverse temporal space, but it seems to be rather permeable and too general to highlight the uniqueness and the specifics of each culture in a close-up view. The factor of "intertwinement" allows us to recognize fragmentary, selective and tessellated interactions in the whole range of Galicia-related topics but it seems to be too narrow to create a differentiated notion of world literature that is clear in its deep structures.

There is one more point that is usually left aside in interpretations of "Austrian Galicia", namely the fact that this potential model demonstrates certain ruptures which shatter the coherence of these "intertwinements". Austrian Galicia was not only a place where diverse cultures, mentalities and ideas crossed, but also a place where a purposeful breakout from intertwinements took place.

Historical facts show a reluctance or inability to be there, e.g. there were multiple waves of migration from Austrian Galicia to other continents as an effort to save entire families from starvation or the concentration or, depending on one's definition, internment camp Thalerhof, which has largely been suppressed in the collective European memory and where numerous Galician people died or left with considerable physical and mental traumas. Among them there can also be found authors who are seldom mentioned today, e.g. Mariika Pidhirianka (Mariia Lenert-Dombrovska).

Hence "Austrian Galicia" as a "European model" in many regards seems to be, principally because of its historic asymmetries, a questionable orientation phenomenon. What is also undisputable is that it possesses segments which could be partially integrated into the modern notion of world literature, which will be examined in closer detail below.

Given the lack of translations of Eastern European texts and mass migration, the process of reformulating world literature cannot be a one-way street but should proceed via cooperation between literary and cultural scholars, historians, literary translators, authors and recipients, i.e. the public. This could be also the focus of network research.

It should be discussed what kind of interdisciplinary approach and what criteria of the new world literature should be taken into consideration, which would be more precise and allow more scope for interpretation than a mere "history of intertwinement", and would offer a long-term model, reflecting those constellations which can stand up to the current structural changes in society. To overcome the challenge of a new world literature on the European level one should first of all bring into play public history as one of the intellectual and publically effective connectors, and involve it in the reformulation of the notion of "world literature".

The re-evaluation of the notion of "world literature" in the 2000s aimed to repeal the dividing line between the centres and peripheries, and took adequate account of the progressing process of globalization. In this context, literary scholars went the way of the public historians who had earlier noticed humans' increased need in the globalized world for a versatile and comprehensive transfer of information and history and - not without some difficulties - founded and developed the discipline now called public history.

Despite fighting for the institutionalization of public history at many European universities, the positions of literary scholars and public historians are quite comparable in the context of text presentation and reception in the globalized world. Moreover, they share the same target groups and their needs. For this commonality speaks inter alia for the fact that in terms of hermeneutics, texts must no longer be separated on the basis of their factuality and fictitiousness, but belong to the same pool of texts which both literary scholars and historians can use (as argued byReinhart Koselleck in his text collection Geschichte - Ereignis und Erzählung [History - Event and Narration] (1973) and Hans 
Robert Jauß in his article Der Gebrauch der Fiktion in Formen der Anschauung und Darstellung der Geschichte. [The Usage of Fiction in the Forms of Ideas and Presentation of History] (1982)).

The European context offers numerous possibilities for a platform which would allow the global public to deal with subjects and perspectives that could become components of the canon of world literature. The potential of a perspective expanded by the so-called post-Soviet literatures would accelerate the overcoming of the still prevalent East-West approach.

The focus of Thomsen's study is “world literature as seen in the Western world" [2].

We should "ask questions about how world literature is structured and evolving in the Western world" [2]. In Thomsen's approach, the Western perspective seems to be predominant and relatively self-sufficient. There is no consideration of what the gaze from the 'East' to the 'West' would look like, but the focus is on the positioning and development of world literature structures in the 'West'. Such a centripetal constellation affords the so-called post-Soviet literatures the status of a literary subject in a new notion of world literature.

Thomsen quite rightly lists the media and economics as an engine of globalization [2]. The advantage of the globalized world is in my opinion the disappearance of rigid dividing lines between the structures in world literature, between the 'West' and the 'East', and the possibility of a change of perspective on different levels, where the respective literatures can be received not in the context of other literatures but in their otherness.

The current war in the East of Europe, namely on the Eastern border of Ukraine, has given rise to a wave of high-quality Ukrainian- and Russian-speaking literature, not only prose but also poetry. Here it is worth mentioning e.g. the poetry of Liubov Jakymchuk The Decomposition ("Розкладання", 2014), in which parallels between the decomposition of the body and of words go along with parallels with toponymy. See also the poetry in Russian by Anastasiia Dmytruk Neither in Terms of Home Country nor in a Maternal Line ... ("Ни по Родине, ни по матери ...", 2014) but also a poetry collection by Iryna Tsilyk Come Back Alive ("Повертайся живим", 2014). Among poetry collections, mention must be made of the anthology Heaven's Hundred Heroes. An Anthology of the Maidan Poetry. (“Небесна сотня. Антологія віршів з Майдану”, 2014) and Dmytro Pavlychko's Poetry from the Maidan ("Вірші 3 Майдану", 2014). A collection of poems published in English is Words for War. New Poems from Ukraine (2017). At the same time, numerous memoirs, prose, journalist texts and photography books were published.

In this way, the threat and military aggression towards the European identity and its unity have caused a globally relevant discursive layer and a cultural and mental space extending onto literature and public history.

The absence of a European-wide platform for the intellectual exchange between authors, public historians, translators and the public is a difficulty on the practical level that should be overcome sooner or later, as there are many texts which remain inaccessible for the global readership solely because of the lack of international channels and translations. The texts which reach the Western reader are not always representative by any means and do not always reflect the literary diversity of the respective country.

Despite open borders, media reports and a number of translations of Ukrainian texts, Ukraine still remains an unknown quantity for Europe, not least because the public historians have not provided an appropriate apparatus for the transfer of knowledge about this country. It is striking that in the framework of public history, significant discourses in terms of intellectual history are inadequate. Hence it seems to me to be sensible to introduce a notion of public intellectual history that possesses interdisciplinary potential and touches on a wider circle of issues, because only such public intellectual history would be able to transfer to the public not only historical but also intellectual, historical and literary ideas.

It is important to note that European intellectual history has segments which are once again becoming highly topical throughout Europe as a whole, especially those concerning European identities. Intellectual history per se is basically linked with public and media history. Also, the intellectuals themselves were part of the public, developing themselves through it or in it. At the same time, intellectual history is a sort of mirror to the public with which the representatives of intellectual history are working.

One should consider the question of the sense of connection between Ukraine and Europe in the context of public intellectual history. The modification of the notion of public history and the introduction of public intellectual history seem to be useful, especially when we discuss the European body of thoughts and appeal to the European readership. This does not relate to the delimitation but to the specification of knowledge transfer with regard to the recipients and "their" past, which is repeatedly overlapping, generating new ideas and having an impact on everyday life even today.

Already, in view of the advanced stage of a new cold war, the annexation of Crimea and with it the violation of international law, the growing migration and globalization show that the European population has an increasing need for stories. A new wave of interest in history as a kind of explanatory model is taking place, allowing people to see the present day more clearly.

As already indicated, there is a need to expand public history with concepts from intellectual history, including literary texts and life writing. It can open up new contexts and interpretations to a wide audience and will be a challenge for literary scholars and authors in particular. It is time to draft a European concept in the framework of public history that could determine the cooperation between Ukraine and other European countries.

Here consideration must be given to the history of literature in the East and West European countries on the international level of communication between the representatives of different academic disciplines on the one hand and academia and the public on the other. In this way, it is possible to establish a responsible and effective information transfer which would coin a long-term European identity and memory policy. 
Thomsen rightly speaks about the new world literature as a paradigm which works as a "supplement to comparative literature and post-colonial studies" [3]. This appears to overlook an important aspect, namely that the new world literature is closely connected with public intellectual history. Constructing the new world literature is not a linear, plannable or controllable process of selection or presentation of texts and authors. It is rather a process of a wide-ranging communication which mostly remains dynamic and productive in its candour.

\section{The SPIRIT OF GAlicia: BetweEn PAST AND PRESENT}

This article deals with Galicia as a representative example of a country's attempts to deal with its own past after the fall of Communism, a past that can also be seen as a European one. The province of Galicia and Lodomeria comprised several regions of today's Western Ukraine and the territories of Southern Poland which were annexed at the end of $18^{\text {th }}$ century by the Habsburgs in the course of the Polish partitions and belonged to them until the fall of the Monarchy in 1918. Galicia remained in every respect the most backward peripheral province of the empire.

Galicia as a subject was not explicitly banned in the Soviet Union but it was extensively adjusted to the communist ideology and to the rhetoric of the class struggle, or just kept secret, especially with respect to Galician intellectual history. Today, Galicia is a kind of historical and literary generator of the country's intellectual history. One can observe a belated mental projection onto the Galician past and identification with the population of Galicia. In modern Ukrainian literature, this past constitutes one of the most interesting segments of the narrative in which a game is being played with the collective self in the historic and societal context.

The nostalgia for Galicia as a striving for the reconstruction of what has been forgotten, for the monarchy and, finally, for the European culture as a counterbalance to so-called Socialist Realism is an attempt to depart from the communist past and its overcoming by turning to the monarchic subjects. This is the specifics of the discourses in Ukraine after the communist occupation.

Galicia is a manifold phenomenon that is largely being appropriated and instrumentalized in a number of countries in many ways. It is a popular subject in at least three states Poland, Ukraine and Austria, whereby Galicia is perceived from a rather narrow perspective, i.e. as a part of the respective states' 'own' past.

An example of a public history approach to Galicia in Austria one can mention the exhibition "Galicia as a Myth" in the Museum of Vienna, while in the media Galicia is promoted first as the "poorhouse of Europe", then as the "Austrian Texas" due to its large oil fields.

Located between public intellectual history and culture is the yearly cultural forum "Doncult" in Ukraine, which takes an interdisciplinary approach to numerous subjects and in this way presents different regions of the country, among them Galicia, from an innovative point of view and from the perspective of diverse artists and authors, and at the same time offers a re-writing of the country's history.
The approach of the Ukrainian authors to Galicia is extremely manifold and largely defies categorization. The mere fact of dealing with this subject testifies to the need for a virtual return by means of narratives into a world that is still intact, marked by the Austrian Enlightenment and attempts at reforms, of a return to life before the big caesura of the strategically well-thought-out and relentlessly pursued mass destruction in the USSR, into a relatively humane dimension that showed no hint of the horrors of Communism and National Socialism.

In Ukraine, Galicia is a reference point to all that could have been experienced by the 'post-Galician' generations. That which has not been experienced permeates the modern literature in various projections and virtualities. It would be unreasonable to classify textual approaches to Galicia in Ukraine as 'longing' and to speak in generalizing fashion of a 'literature of longing'. It is rather a literature of reconstruction and an intellectual attempt to come to terms with the past, a literature filling in a cultural, lingual, historical and ultimately mental gap in the societal development.

As already indicated, certain asymmetries adhere to "Austrian Galicia" in terms of a model of European multiculturalism, which on the one hand requires a differentiated interpretation and on the other can be integrated into the new notion of world literature - albeit as a brittle, inwardly focused and introverted fragment.

In this article, the texts on Galicia are presented under an integrative aspect, namely as a literature of Ukraine after the fall of Communism and therefore as a literature bridging historical epochs, dealing with its own identity under different historical circumstances. The combination of history and identities basically makes these texts part of world literature in terms of the development of identities in the historical-political context. They can be seen as a sort of literature of resonance, as they usually deal with sustainable 'vibrations' of identities in different states.

Of all things, this interaction between history and the development of identities makes them one of the central subjects of both public history and literature.

\section{YURII AND SOFIIA ANDRUKHOVYCH: THE AUSTRIAN CONNECTION TO GALICIA}

Since it is impossible to analyse all texts related to Galicia in this article, a selective cross section of the most representative will be presented. The texts are located both in literature and history and, in view of an increasing public interest, also in public intellectual history, which makes them especially interesting in the context of Thomsen's approach to world literature.

Yurii Andrukhovych (*1960), who lives in the West Ukrainian city Ivano-Frankivsk, is one of the most famous and most translated Ukrainian authors and is a frequent and welcome addition to West European discourses. The subject of Galicia is a constant aspect of his work. His novel Twelve Rings (2003) is probably the most representative example of an examination of Galicia in Ukraine. The main protagonist is the Austrian Karl-Joseph Zumbrunnen, who is explicitly 
called a former subject of Austria and at the same time acts as a medium between the pre-communist Austrian and post-communist Ukrainian world. He is one of the few Austrians to regularly venture to Ukraine in the 1990s after the fall of the USSR. He writes letters to his doubting compatriots about a country that he became fond of in spite of everything.

He criticizes Ukrainian society, its representatives with their habits and the Soviet mentality with its pseudo-values. Through the eyes of a 'subject' of the monarchy, the novel presents a 'lost Ukraine' which is nevertheless still alive both for him and for its inhabitants.

Galicia is his personal location, even if still a strange one, which he is keen to explore. The Austrian receives the feeling of the lost Europe in the hotel "Georges" in Lviv. Whether it is the centre or the periphery remains in an open question in the text. As an epigraph the author chose the lines of Bohdan-Ihor Antonych (1909-1937) and hence makes this until recently forgotten Ukrainian writer, poet, translator and literary scholar a code to modernity and to a tragic hope for survival for Ukrainian society.

My Europe (2005), the book published by Yurii Andrukhovych in cooperation with Andrzej Stasjuk, centres on the striving of authors to identify themselves with Europe. In Andrukhovych's essay Central Eastern Revision (2005), ruins as a representation of the past world are central, among them also the ruins of languages, words and texts, which he calls the "mobile memory" [Andrukhovych, 76, 2005]. With a hint of sarcasm, he presents the debates between intellectuals from Western and Eastern Europe, which occasionally takes on grotesque forms when the incapability of the "West" to understand "the East" comes to light.

The spotlight is on the question of the perception of history and the need for such perception in the respective societies. Questions such as “Звільнumu майбутнє від минулого? Звільнити минуле від майбутнъого?” [Stasjuk and Andrukhovych, 127, 2005], [4] remain unanswered, as does the question of the communication between "Europe" and "us".

In the journalistic work of Andrukhovych, especially the pieces published in Weekly Mirror, he presents his perception of Europe and particularly of Austria. He undertakes in different genres a sort of intellectual restitution of that which has not been experienced - part of that is Galicia, which for him is as European as Ukraine itself.

From the perspective of this author calling Europe "mine", Europe should discover itself, also thanks to Ukraine and with its help: “[...] нам випадає особливо почесна місія довести Свропі, що вона значно більша, ніж сама себе уявляє. Призвичаїти іï до думання про себе інакше. До іншого розуміння себе і чим вона врешті є. І цим самим, можливо, врятувати іiі.“" [Andrukhovych, 2006], [5].

Sofiia Andrukhovych (*1982) follows in her father's footsteps with her novel Felix Austria (2014), in which she depicts with photographic precision the life of the Galician city Ivano-Frankivsk at the turn of the century. Despite the verbosity of the text and the static characterization of the two female protagonists - women who live in this city and whose fates are tightly interwoven - the author offers an interesting and detailed vision of the seat of the monarchic district with numerous profiles of its inhabitants and their personal stories. The city and its individuals are a sort of body subdued to the influence of time, a body which is changing through history but also through the writing of stories.

The visuality, emotion and sentiment in the reconstruction of the past seems to be the crucial part of the novel. The decision concerning to what extent the Austria reflected can be named "felix" is left up to the readership.

\section{YURII VynNyChUK: Galicia AS A MulticUltural MYSTERY}

The writer Yurii Vynnychuk (*1952) from Lviv turns Galicia into a popular intrigue. In his book The Legends of Lviv (2 volumes, published in 1999 and 2009 respectively) he offers short and fanciful stories from the life of the city from several centuries, long before Galicia became "Austrian", although the time of the monarchy is not neglected.

Extensive layers of Ukrainian history, among them the period of the Principality Galicia-Volhynia, are presented in an elegant and humorous style. The multiculturalism of the city in which Ukrainians, Poles, Jews, Armenians and Roma coexisted becomes the subject of a creative building of myths, where the world view and the self-perception of the respective ethnicities are expressed through folklore.

Vynnychuk's novel The Tango of Death (2013), which centres on the multiculturalism of Lviv before and during WWII, should be also mentioned. The author handles both the lives of the protagonists and the presentation of the city rather unrealistically and with highly dense colours.

In the near future, Vynnychuk's and Kurkov's novel, written in cooperation, should be published, a work dealing with the Galician knights who took part in crusades - in this context too, Galicia clearly offers abundant material for new discourses for both literature and public history.

For Vynnychuk, the style, subject and the approach to Galicia as well as to his home city, where he grew up and wrote but not for publication, seem to be, to a large extent, bound to his aversion to Socialist Realism.

Similarly to Sofiia Andrukhovych's Ivano-Frakivsk, the Lviv of Vynnychuk is even sensorially tangible. The images of these Galician cities are built up rather via masterly depiction than through intellectual constructions. What is undisputable is that in the novels of both Sofiia Andrukhovych and Yurii Vynnychuk language rich in Polonisms, which can only be called "Galician" with some reservation, serves as a counterweight to the Russification carried out in the USSR. Such language makes an innovative impression and can be interpreted as a link to Galicia, where the Polish culture, language and national ideology dominated, but it will nonetheless be a challenge for most readers. However, it doesn't reduce the literary significance of the texts.

The search for Europe through Galicia in the above-mentioned texts takes the form of a game between verbal photography and fantasy in which the self of the writer is moving and is sometimes entangled. 


\section{StePan Prociuk: Philosophical Resistance to Nostalgia}

Stepan Prociuk (*1964) is, along with Oksana Zabuzhko, one of the few Ukrainian authors whose works deliver not photography but logical, analytical and psychological structures. They develop a philosophy which doesn't rely on mere depiction. Although Prociuk writes in diverse genres, his intellectual prose located between existentialism and psychology is translated neither into German nor into English.

The genres he experiments with are broad: from the sociocritical psychodrama The Infection (2002) and the youth literature Mariika and Kostyk (2008), and an essay collection characterized by classical psychoanalysis, Blood Diagnosis (2010), to the novel The Destruction of the Doll (2010) and highly innovative life writing texts The Masks are Falling Slowly (2011), The Black Apple (2013) and The Rose of the Ritual Pain (2013).

With regard to Galicia, two texts are interesting for us: The Infection (2002) and The Rose of the Ritual Pain. A Novel about Vasyl Stefanyk (2010).

The first text deals with the generations of the Soviet era and the years after the fall of the USSR and the second deals with the psychogram of Vasyl Stefanyk, a Ukrainian writer and founder of Expressionism born in Galicia who witnessed the Bolshevik takeover and the Holodomor (1932-1933). Holodomor, or - literarily - killing by hunger, is the definition of the famine in Ukraine which was artificially carried out by the Communist Party and its leaders. According to the historian Robert Conquest, 14.5 million people became victims of this crime, as he indicates in his book The Harvest of Sorrow. Soviet Collectivization and the Terror-Famine (1987). The number of victims varies across different sources differently and needs further precision. One should bear in mind the political explosiveness of this issue and of the open question of the criminal liability for this crime against humanity, which is largely politicized and subjectivized, and thus exacerbates further research on the subject.

In both cases, Galicia is a permanent reference point in the mosaics of the political, historical and personal modalities as a firm component of an identity which is accepted by the self or by the environment or of an identity growing stronger because of the pressure or isolation under the Soviet regime or, on the contrary, increasing in strength in resistance to the system (The Infection). This component can also take the form of a 'backward' period isolated from modernity with dramatic human microcosms serving as source of inspiration for the writer working between Vienna and Galicia (The Rose of the Ritual Pain).

The psychological pulse of both texts beats in the historical context and is presented without any nostalgia. It can even be defined as ironic and analytical anti-nostalgia against any kind of colonialism and all mental dependencies of the human consciousness referring to it.

Prociuk's Galicia is a place producing intellectual history and certain types of psyche.

The author integrates Galicia, its culture and history, into the psychological profiles of his protagonists and develops a representative image of how a society can handle its historical memory.

The Infection captures an essential feature of homi sovietici, in particular that of agricultural Galicia, namely the mimicry which forced them to the most extreme self-denial on all possible levels in their urban, totally ideologized and russified milieu marked by the Soviet vacuum of values.

This infection of self-destruction in service of the system or in adaptation to it lives on in the post-dictatorial era in the next generations. The resistance of the 'self' to the cultural, linguistic and mental uniformity, brought about by physical and mental violence, to any simulacra as a legacy of the USSR or the renunciation of resistance is presented in the text as a free and at the same time dramatic choice of each citizen despite the pressure of the regime or external circumstances. Thus, the novel offers a broad surface onto which many generations of this country can project their innermost desires and interests.

The biography of the Galician writer Vasyl Stefanyk (1871-1936), The Rose of the Ritual Pain, is a psychographic novel about an intellectual who was born, lived and worked in the Habsburg Empire. Galicia is a world sui generis, on the one hand one of the core elements of Stefanyk's inner life, and on the other a diagram of the interplay between the structures of the respective political systems and the psychological life of the intellectual.

With the biography of Stefanyk, who was the voice of the disastrous situation of the Galician peasants, the advocate of their interests in the Austrian parliament and a witness to the Bolshevist despotism after 1918, Prociuk provides a new quality in our perception of Galicia. He offers an intellectual history of the deformation of a period of time, seen through the inner and external life of the writer. Galicia is recorded polyphonically in this philosophical psychograph.

\section{NATALKA SNIADANKO AND NATALIIA HURNYTSKA: EXOTIC GALICIA AS ENTERTAINMENT}

Galicia also provides Ukrainian authors with sufficient material for entertainment. Two texts by Ukrainian female writers are interesting in this regard: Natalka Sniadanko's novel A Herbarium of Lovers (2011) and Nataliia Hurnytska's novel A Coffee Melody in the Pitch of Cardamom (2013). Sniadanko (*1973) relates with great linguistic and stylistic skill a story with an absurd-grotesque, even satirized image of Galicia.

Hurnytska gets by with a linguistic minimum, but masterfully handles traditional topics and historical background from Galician life of the $19^{\text {th }}$ century. However, the absence in both texts of any pretensions to substantial intellectual content makes them housewife's literature with elements of erotica.

Hurnytska tells us a story of a love banned for social reasons, while Sniadanko in contrast creates an almost parodistic vision of the female protagonist's feminist approach to self-realization, not least in terms of sex.

The factor of nostalgia for Galicia is voiced in both texts in a very simple and sometimes naïve form. Here Galicia is 
almost the exotic world of Sacher-Masoch, a kind of kitsch decoration which aims to satisfy the reader's curiosity. As a matter of course, the authors thereby operate with multicultural subjects, e.g. the love between a rich Polish man and a poor Ukrainian woman in Hurnytska, or establishing a harem with handicapped men of different nationalities and ethnicities in Sniadanko. In the novels, we can observe an attempt at revision of women's issues- in this regard the authors are unique.

Sniadanko raises the question of female otherness and thinking differently in a world dominated by males - in the world from which mentally or physically handicapped men are also excluded. The main female protagonist deliberately chooses the 'male' lifestyle. She becomes happy and there is no society that can prohibit it - neither the provincial Galician nor the 'central' one in Paris where she finds herself in the course of time. She is assertive in business, in politics and in her private life. Hurnytska also deals with the exclusion of the woman from society because of her social status, her nationality and financial situation. This female protagonist also fights to be happy, but she sees her happiness in traditional values like family and children. It is not about resistance to conventions but about adjusting to society with the minimum of personal losses, and ultimately, she succeeds in doing so.

The authors offer a risqué and emotionally charged image of Galicia as a place where womanhood is on the one hand oppressed and on the other could be promoted. The battle of the sexes and the question of the integrity of human existence independent of gender and physical condition thus receive their literary platform.

\section{TARAS PROKHASKO: Galicia AS A Kind OF SELF-TESTIMONY}

The writer Taras Prokhasko from Ivano-Frankivsk (*1968) compiled a book from his three-minute performances in the radio program The Diary broadcast from Monday to Friday on the Ivano-Frankivsk radio station The Tower. This kind of transition from public media presentation to book form is a prime example of the interaction between public history and literature.

What is more interesting is the fact that in this case we are dealing with a rudimentary genre in Ukraine, self-testimonies, i.e. ego documents, which are presented both orally and in written form. The range of subjects in the book, which is called, like the radio station, FM Halychyna (2001), is broad and embraces personal experiences with regard to Galicia, Western Ukraine and Central Europe. It deals with, among other things, childhood, history, migration, the fates of families, violent deportations and the fight for freedom.

The record dated January $28^{\text {th }}$ documents e.g. the presence of Europe in the mentality of Ukrainian citizens and at the same time their ignorance of their own geography, their incapability to find and to localize themselves in their own country.

But this very powerlessness regarding Ukraine seems to unify the Ukrainian with the European readership - by creating an opportunity for a voyage of discovery through Ukraine and finally through Europe.

Prokhasko also follows up with the topic of Galicia in the collection For It Is How It Is (2010), also comprising FM Halychyna. In this collection there prevails an impressionistic, fragmentary and mosaic-like atmosphere of memories with geographical, personal and temporal overlaps. His Galicia gains in significance as a result of a chaotic impression, open in terms of postmodernity.

\section{CONCLUSION}

The literatures that have arisen after the fall of the USSR are, in their variety of languages, subjects, genres, contexts and approaches, to a large extent unknown to the Western European reader. Therefore, the efforts to re-think the notion of "world literature" should go hand in hand with the focus on rapprochement with these literatures. For this reason, an interdisciplinary international communication platform on the level of public intellectual history is needed.

Dealing with Galicia in Ukrainian intellectual circles, as shown in this article via some representative examples, contains huge potential for such rapprochement, especially with regard to the multicultural and colonial European past.

The Galician world is thus not just a literary subject. It is both a segment of postmodern European intellectual history and a moment of a regional identity, as indicated by Stefan Simonek in 2012 in Der Habsburger-Mythos als Moment einer regionalen Identität Galiziens? Beispiele aus der zeitgenössischen ukrainisch-galizischen Literatur [The Habsburg Myth As a Moment of a Regional Identity of Galicia? Examples from the Contemporary Ukrainian-Galician Literature], which, in my opinion, on the one hand develops traditions preserving the state but on the other offers a great temptation for the former colonial countries to see in it a moment of the past imperial identity of power.

\section{REFERENCES}

[1] "The global process of de-canonization and of elimination of the cultural centre is advantageous for Ukrainian literature. Today, it has become possible for it to take its own place in a number of the national literatures, as was the case with the literatures of Egypt, Israel, Estonia, and Nigeria et al., [...] Today Ukrainian literature breaks with its [...] centre or with the old canon and creates new criteria for its construction. [...] The colonialism lay in the fact that everything in this canon proceeded according to a determined matrix, to a pattern, namely Russian literature". S. Pavlychko, Канон з погляду боротьби центру i марriнecy [The canon from the perspective of the fight between the centre and the periphery], in ibid. Теорія літератури [The theory of literature], 2st ed. Kyiv, pp. 627-636 (p. 634), 2009. All the translations from the Ukrainian in this article are by the author.

[2] M. R. Thomsen, "Mapping world literature," International Canonization and Transnational Literatures, London, New York, p. 3, 2008.

[3] Y. Andrukhovych, “Центрально-східна ревізія” [Central Eastern revision], in Andrzej Stasjuk and Yurii Andrukhovych: Моя Європа [My Europe], Lviv, pp. 69-127 (p. 76), 2005.

[4] "To free the future from the past? Or the past from the future?" Stasjuk and Andrukhovych, Европа (see note 3), p. 127.

[5] "[...] an honourable mission is bestowed upon us - to prove to Europe that it is much bigger than it assumes. We make it think about itself and perceive itself differently - in the form as it actually is. Maybe Europe can be saved in this way." Y. Andrukhovych. (23.10.2006). В потязі Базель-Берлін [On the Basel-Berlin train]. Дзеркало тижня [Weekly mirror]. [Online]. 03.11.2006. Available: http://www.gazeta.dt.ua/CULTURE/u_potyazi_bazel_berlin,_23102 006.html 


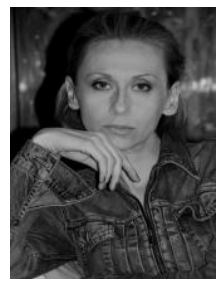

Lesya Ivasyuk was born in Ukraine, in Kalush, which formerly belonged to the historical region called "Galicia". In 1997 she completed an internship on the Committee on the Restitution of Purloined Cultural Assets in World War II, The Cabinet of Ministers (Kyiv, Ukraine).

In 2001 she received a master of philosophy degree at the University of Vienna in Austria with the diploma thesis The notion of Evil in the Nibelungenlied: A Psychoanalytical Study of Kriemhild. In 2014 she obtained her PhD in German studies at the University of Vienna, where she worked at the Institute of Slavonic Studies as a PhD candidate from 2010 to 2014 and wrote her PhD dissertation The Literatures on the Revolution of 1846 and their Perspectivizations. She previously worked as a foreign correspondent for the newspaper Svoboda in New Jersey (USA) and for the news agency Ukrinform in Kyiv (Ukraine). Now she works as an independent scholar, literary translator and columnist in Austria and Ukraine. Her monograph Die polnische Revolution von 1846 in Galizien: Österreichische, ukrainische und polnische Wahrnehmungen [The Polish Revolution of 1846 in Galicia: Austrian, Ukrainian and Polish Perception] was published in 2017 (Wiesbaden: Springer Verlag). She also translated, edited and wrote the foreword and the bibliography to Edith von Salburg's novel: Der Sohn der Ukraine [The Son of Ukraine], Kyiv: Tempora, 2014. In the field of public history she edited, translated and wrote the foreword to the memoirs of Petro Kowal Діти берегів часу [The Children of the Water Sides], Lviv: Svit, 2017. Her research interests are Ukrainian literature, Ukrainian-Polish relations, revolutions from the interdisciplinary perspective, public history and post-colonial studies.

Dr. Ivasyuk is a member of the research group "Austrian Galicia and its Multicultural Heritage" at the University of Vienna. In 2017, the memoirs of Petro Kowal, The Children of the Water Sides, about Operation Vistula in 1947 - the book edited, translated and with a foreword by Lesya Ivasyuk were awarded first prize by the Foundation of the Ukrainian Free University (USA). 